\title{
O gozo do proibido: mulheres em Musa Praguejadora
}

\author{
Patricia Horta ${ }^{\mathrm{i}}$
}

\begin{abstract}
RESUMO
A obra Musa Praguejadora (2014), de Ana Miranda, constitui material interessante para análise do hibridismo típico do gênero biográfico, à luz das práticas da literatura contemporânea. Identificada como biografia de Gregório de Matos e Guerra, Musa Praguejadora reconstitui o arco de existência do poeta seiscentista e o ambiente da Bahia colonial, por meio de costura original de minuciosa pesquisa histórica com releitura de poemas do biografado. Mas Musa Praguejadora é também uma reflexão sobre a condição das mulheres no século XVII, no Brasil e em Portugal. Neste trabalho, demonstra-se como Ana Miranda mobiliza recursos literários para construir uma imagem de mulheres que não apenas se submetiam à opressão patriarcal, mas também criavam espaços de resistência e realização.
\end{abstract}

Palavras-chave: Romance biográfico; Metaficção historiográfica; Ana Miranda; Gregório de Matos e Guerra.

\begin{abstract}
Musa Praguejadora (2014), by Ana Miranda, constitutes interesting material for the analysis of the typical hybridism of the biographical genre, in the light of contemporary literature. Identified as a biography of Gregório de Matos e Guerra, Musa Praguejadora reconstructs the arch of existence of the 17th century poet and the environment of colonial Bahia, through original sewing of detailed historical research with re-reading of Matos' poems. But Musa Praguejadora is also a reflection on the condition of women in the 17th century, in Brazil and Portugal. In this work, we demonstrate how Ana Miranda uses literary resources to build an image of women who did not submitted to patriarchal oppression only, but also created spaces of resistance and fulfillment.
\end{abstract}

Keywords: Biographical novel; Historiographic metafiction; Ana Miranda; Gregório de Matos e Guerra.

\footnotetext{
${ }^{i}$ É Mestre em Literatura Brasileira pela Universidade de São Paulo. Possui graduação em Letras Português e Alemão pela Universidade de São Paulo e Licenciatura em Letras - Inglês pela Fundação Educacional de Machado. Tem experiência docente na área de Letras, com ênfases em Estudos Literários, Literatura Brasileira e Redação Técnica. Foi Diretora Adjunta Acadêmica no IFSP Sertãozinho e Diretora Geral de implantação do IFSP Araraquara. Coordenou o Curso de Formação Pedagógica do IFSP Sertãozinho. Trabalhou na equipe técnica para implantação do Centro de Línguas e da Licenciatura em Letras do IFSP Sertãozinho. Atualmente cursa Doutorado em Literatura Brasileira na Universidade do Estado do Rio de Janeiro.

E-mail:patriciavirtual@gmail.com
} 
A obra Musa Praguejadora, de Ana Miranda, publicada em 2014, constitui material interessante para análise do hibridismo típico do gênero biográfico, à luz das práticas da literatura contemporânea. Identificada como biografia de Gregório de Matos e Guerra, Musa Praguejadora reconstitui o arco de existência do poeta seiscentista e o ambiente da Bahia colonial, por meio de costura original de minuciosa pesquisa histórica com releitura de poemas do biografado.

Ana Miranda já havia explorado a figura de Gregório de Matos em Boca do Inferno, de 1989. A obra marca a entrada da escritora no universo literário brasileiro e apresenta ao público as características mais relevantes de seu estilo: a mistura de literatura e história e o reaproveitamento dos textos dos escritores que são personagens de seus romances.

Desde a obra de estreia, Ana Miranda publicou outros cinco livros que tratam da vida de escritores brasileiros: A última quimera (1995) trata de episódios da vida do poeta Augusto dos Anjos; a novela Clarice (1996) faz da escritora Clarice Lispector uma personagem ficcional; Dias e dias (2002) e Semíramis (2014) reconstituem as vidas dos românticos Gonçalves Dias e José de Alencar, respectivamente. Finalmente, Musa Praguejadora (2014) adiciona-se à lista de obras que tratam da vida de escritores brasileiros, mas distingue-se dos anteriores por apresentar-se em forma de biografia, não de romance. Nesta obra, a escritora cearense salienta as tensões típicas do gênero biográfico, como: o hibridismo, a implicação do biógrafo na seleção e na interpretação de documentos, o intertexto, as genealogias discursivas, a construção da identidade do biografado, entre outras, de modo a utilizá-las e questioná-las, ao mesmo tempo. Desse modo, constitui seu texto como uma metaficção historiográfica (ou uma metabiografia), nos termos de Linda Hutcheon, por portar uma estrutura autorreflexiva e paródica, altamente implicada naquilo que deseja criticar (HUTCHEON, 1991).

No plano formal, por exemplo, Ana Miranda reforça a tensão entre a elaboração literária e a reconstrução de fatos históricos ao distinguir visualmente os dois tipos de escrita. Conforme explicação da própria autora no final do livro, as partes grafadas em itálico são ficcionais ou adaptações de poesias de Gregório de Matos (MIRANDA, 2014, p. 2014). Portanto, as partes em fonte convencional são reconstituições de fatos históricos, das relações sociais da Bahia do século XVII e de passagens da vida do poeta baiano. Como os dois tipos de escrita são complementares e interferentes, a distinção 
demonstra que a elaboração biográfica depende da construção ficcional, de modo a intensificar as reflexões sobre o gênero biográfico e o discurso histórico, usando sua própria estrutura.

Tal modus operandi, que intensifica um questionamento para desencadear reflexões acerca dele, repete-se em vários aspectos de Musa Praguejadora. Dentre eles, destaca-se, no presente trabalho, a elaboração da figura feminina.

A presença do feminino é marcante na obra de Ana Miranda. A órfa Oribela e a dançarina Amina, protagonistas dos romances Desmundo (1996) e Amrik (1997), são vozes de resistência em reconstituições históricas do Brasil, que retratam a sociedade dominada pelos arbítrios patriarcais. Bambi, narradora-protagonista de Sem pecado (1993), rememora os enfrentamentos de sua adolescência, quando recém-chegada à cidade grande. Dias e Dias (2010), embora baseada na biografia de Gonçalves Dias, é a história de Feliciana, narradora-personagem, e seu amor platônico pelo poeta. Da mesma forma, Semíramis (2014) tem como fio condutor a vida de José de Alencar, mas trata da relação das irmãs Semíramis e Iriana, esta última narradora do romance.

Desse modo, a biografia de Gregório de Matos por Ana Miranda é também uma reflexão sobre a condição das mulheres no século XVII, no Brasil e em Portugal.

O capítulo "O gozo do proibido", que trata de "freiras e freiráticos" (MIRANDA, 2014, p. 147-154) é de especial interesse para a análise da presença feminina na obra e dos processos de escrita de Ana Miranda.

O capítulo é introduzido por um desenho arrojado do artista francês JeanJacques Lequeu, que retrata uma freira em pose sensual. A imagem do artista francês, intitulada "Et nous aussi nous serons mères; car!" (1794), já havia sido capa da antologia de poemas freiráticos dos séculos XVII e XVIII, intitulada Que seja em segredo, organizada por Ana Miranda e publicada em $1998^{1}$.

No capítulo "O gozo do proibido", após uma breve narrativa ficcional do flerte de Gregório de Matos com uma jovem freira (MIRANDA, 2014, p. 148-149) - já imaginada, sem nomes atribuídos, em Que seja em segredo (MIRANDA, s/d, ebook) Ana Miranda inicia o registro histórico da vida nos conventos, indicando algo já muito sabido: que a vocação religiosa não era levada em conta para o ingresso nos conventos, e sim o interesse da família, seja para ter uma freira entre os descendentes, seja para 
afastar da sociedade as moças com comportamento considerado inadequado. Em seguida a autora rompe o senso comum, ao afirmar:

\begin{abstract}
No convento, essas moças ficavam distantes da opressão de seus pais, irmãos ou esposos, e desfrutavam de uma liberdade que lhes permitia realizar muitos caprichos e desejos interditos. Podiam aprender a ler e a escrever em português, latim ou espanhol, tinham à disposição livros numa biblioteca, e umas se tornavam escritoras, intelectuais, poetisas. Outras aprendiam solfa e a tocar instrumentos musicais, cantos e canto coral. Ilustravam-se. (MIRANDA, 2014, p. 150)
\end{abstract}

Todo o trecho do qual se destacaram as passagens citadas é uma reescrita das afirmações feitas na Introdução de Que seja em segredo. Tanto na antologia de 1998, como na biografia romanceada de 2014, Ana Miranda demonstra que a clausura libertava as mulheres da opressão e da ignorância que lhes eram impostas pela sociedade patriarcal seiscentista. Na reclusão, eram capazes de materializar seus desejos, tantos os intelectuais, demonstrados no trecho acima, como os carnais: "Mas algumas se tornavam cortesãs e mestras no amor sensual, pois nem todos os amores freiráticos eram platônicos" (MIRANDA, 2014, p. 150).

O capítulo "O gozo do proibido" é exemplar para se compreender a construção da figura feminina em Musa Praguejadora. Em toda a obra, como nesse capítulo, Ana Miranda recupera os discursos, modernos ou da época de Gregório de Matos, que revelam as terríveis limitações sociais que sofriam as mulheres do século XVII. Porém, como as freiras desse capítulo, outras mulheres em Musa Praguejadora encontram lugares de resistência dentro do sistema patriarcal e opressor, como se verá.

O fato de ser o texto de "O gozo do proibido" uma reescrita, ou uma reafirmação de discurso anterior da autora tem importância que extrapola o âmbito de Musa Praguejadora. Indica a possibilidade de a construção feminina presente nesta biografia ser recorrente na obra de Ana Miranda. É um indício que fica para ser aprofundado em futuros estudos, mas que é reforçado pela fala da autora em entrevista ao Jornal do Commercio:

\footnotetext{
Não gosto desta história de fazermos as mulheres de vítimas, as mulheres sempre foram uma grande força, sempre foram longevas, bem dotadas, perceptivas, sensitivas, intuitivas, cruéis, magnânimas, sedutoras, uma força da natureza, claro, a natureza precisava preservar a espécie dotando de força de sobrevivência e resistência as que carregavam a cria no ventre e a alimentavam. (Fala de Ana Miranda em: GUEDES, 2015)
} 
De qualquer forma, pode-se sondar uma retórica da superioridade feminina em Musa Praguejadora, por exemplo, na comparação feita entre Gregório de Matos, pai do poeta, e a mãe, Maria da Guerra: "Não parece ter sido autoritário, ou severo; ao contrário. Dá a impressão de um homem distraído, complacente, atrevido, malicioso, comandado pela autoridade paterna, à sombra da personalidade mais forte da esposa" (MIRANDA, 2014, p. 77, grifos nossos). Além disso, Ana Miranda dedica dezoito páginas à representação da mãe do poeta, e apenas cinco à do pai.

No entanto, essa pretensa superioridade não está no reconhecimento da sociedade descrita em Musa Praguejadora. Por se tratar de personagem histórica de quem pouco restou de documentos, Ana Miranda recorre a descrições e estudos sobre a Bahia do século XVII para imaginar historicamente a vida de Maria da Guerra. A autora revela esse procedimento no próprio texto: "Pode-se recriar o cotidiano de Maria da Guerra, a mãe do poeta, assim como o de outras mulheres brancas, a partir das anotações de viajantes ou observadores que estiveram na Bahia [...]" (MIRANDA, 2014, p. 62).

Portanto, a personagem Maria da Guerra funciona como modelo da vida das mulheres brancas dos seiscentos no Brasil, além de mãe de Gregório de Matos. Por meio de Maria da Guerra, Ana Miranda propõe reflexões acerca da vida feminina na elite branca da época, lançando mão não só das descrições dos viajantes, como também de estudos de História e Antropologia.

A elaboração da figura de Maria da Guerra ocorre, como de praxe em Musa Praguejadora, na relação complementar entre "eixo ficcional" e "eixo documental". Nos dois "eixos", Ana Miranda promove diálogos com outros textos, em especial de pesquisadores, para reconstruir três aspectos da vida feminina branca na Bahia seiscentista: a dura realidade das mulheres, seu cotidiano social e circunscrições de resistência feminina.

A primeira referência direta a Maria da Guerra no "eixo documental" é estabelecida por uma relação dialética entre o discurso de Manuel Pereira Rabelo e a narradora histórica da obra:

Maria da Guerra era "matrona geralmente conhecida de respeito em toda a cidade: cujas prendas intelectuais amassaram uma trindade de talentos capaz 
de resplandecer no coração da mesma Roma”, diz Manuel Pereira Rabelo. A matrona dotada de prendas intelectuais não sabia ler e escrever, como quase todas as mulheres de seu tempo. (MIRANDA, 2014, p. 57)

Destaca-se o efeito causado pelo contraste entre "prendas intelectuais" e analfabetismo, que reforça a situação de exclusão das mulheres. Não se pode atribuir ao texto de Rabelo uma idealização romântica de Maria de Guerra. O autor segue as normas do modelo encomiástico clássico de sua biografia, que deve elogiar a progenitora de seu biografado, branca e da elite, nesse caso usando o locus Educatio et Disciplina.

Ana Miranda problematiza o lugar-comum clássico e contra-argumenta com outro texto, escrito em 1651, a Carta de guia de casados, que: "diz que as mulheres precisavam apenas das primeiras letras, pois seu melhor livro seria a almofada e o bastidor” (MIRANDA, 2014, p. 57). E ressalta que, na colônia, a maioria das mulheres estava aquém das primeiras letras, pois não sabia nem mesmo assinar o nome, como era o caso de Maria da Guerra (MIRANDA, 2014, P. 57).

Um pouco mais adiante, Ana Miranda explica a expressão, usada por Rabelo, "matrona conhecida de respeito em toda a cidade": "significava que se comportava de acordo com as normas da moral e dos bons costumes" (MIRANDA, 2014, p. 58). Portanto, exclui-se de Maria da Guerra, como das mulheres dos seiscentos, qualquer reconhecimento por "prendas intelectuais" de fato, e o elogio ganhava-se pelo comportamento adequado às regras sociais.

Conforme o texto de Ana Miranda, desde cedo, as mulheres do século XVII eram vigiadas pelos homens que as cercavam, pais, irmãos e padres, "pois a Igreja exercia intenso controle sobre o comportamento feminino, reafirmando que os homens eram superiores, dotados da autoridade e do mando" (MIRANDA, 2014, p. 58). Destaca que: "No Brasil a reclusão das brancas era mais severa do que no Reino" (MIRANDA, 2014, p. 58) e ilustra a afirmação com o comentário do explorador francês François Froger de que: "as mulheres na Bahia lhe causavam pena" MIRANDA, 2014, p. 58).

Analfabeta, reclusa, intensamente vigiada: o esboço da jovem Maria da Guerra, recém-casada, e de seu ambiente opressor prepara a construção da personagem estática descrita no capítulo seguinte, "Vida de casada", que se propõe a reconstruir seu cotidiano. No "eixo documental" do capítulo, a partir de suas pesquisas, Ana Miranda elabora cenas de eventos sociais realizados no dia a dia colonial e insere aí a figura de 
Maria da Guerra, aos moldes dos desenhos e pinturas dos exploradores coloniais, como, por exemplo, no trecho abaixo:

\begin{abstract}
As pessoas costumavam levar seus bancos, cadeiras, almofadas e outros assentos para a igreja, e localizavam-se de acordo com a hierarquia social, ficando à frente os mais ricos e poderosos, decrescendo até os escravos e chulos que permaneciam do lado de fora da igreja. Decerto Maria da Guerra estava nas primeiras posições, ao lado de seu marido fidalgo, sua mãe e seu sogro rico. (MIRANDA, 2014, p. 67)
\end{abstract}

O procedimento é recorrente ao longo do capítulo, seja na descrição do cotidiano regulado pela Igreja: “A vida religiosa estava acima de tudo. Maria acompanhava procissões(...)" (MIRANDA, 2014, p. 63); ou na de eventos especiais: "Havia uma tradicional cavalhada no terreiro, a que Maria da Guerra decerto assistia" (MIRANDA, 2014, p. 68).

Maria da Guerra, modelo da mulher branca da elite na vida colonial brasileira, não tem ação nenhuma no "eixo documental”. Aparece imóvel, vestida e localizada de acordo com sua posição social, não demonstra sentimentos, participa dos eventos de modo convencional, criando uma figura fortemente significativa da condição das mulheres na colônia.

Já no "eixo ficcional", a narração onisciente seletiva permite o desenvolvimento de Maria da Guerra em ação. O discurso indireto livre traz para a cena as atitudes, os pensamentos e os sentimentos da personagem, mas que são determinados pelos costumes da época, a partir da incorporação dos discursos históricos e antropológicos do “eixo documental”. É o que pode se verificar no momento em que Maria da Guerra se prepara para o casamento:

Tem Maria da Guerra o corpo de menina quando a aia de quarto a veste para se casar, com um vestido branco de cassa cheio de folhos e pregas, corpete franzido, uma faixa de fita azul caindo para trás. A mãe lhe entrega uma bolsa esmoleira de tafetá, que foi de seu próprio casamento [...] Maria toma nas mãos um missal encadernado em madrepérola, um terço, uma cruz de ouro, que foram de dona Margarida Álvares, a falecida mulher de seu padrasto. A menina se olha no espelho, acha-se de boa figura. Este é o dia mais importante da sua vida. Daí, então, aos doze anos de idade, passará a mulher. (MIRANDA, 2014, p. 57)

No trecho acima, a figura e as atitudes de Maria da Guerra são elaboradas a partir de elementos derivados das pesquisas da autora sobre vestimenta, adornos e 
costumes coloniais. A composição forma um conjunto pictórico, emoldurado por um elemento determinante: a tenra idade da noiva.

Assim como no "eixo documental", no "eixo ficcional” Maria da Guerra é uma personagem que não exerce poder de escolhas. "Acha-se de boa figura", ao estar paramentada ao gosto social. Conclui, com certo orgulho, que "passará a mulher", mas essa condição não lhe trará autonomia. Até mesmo a composição de Maria da Guerra não se realiza a partir de elementos pessoais ou documentos históricos de sua existência, mas sim a partir de discursos gerais sobre a vida na colônia, dos pesquisadores consultados e selecionados pela autora.

Construída a partir de discursos alheios, Maria da Guerra não possui existência discursiva própria em Musa Praguejadora. O leitor não acessa sua voz, suas idiossincrasias. Na cena destacada, da preparação para o casamento, assim como na maior parte da construção da personagem no "eixo ficcional", Maria da Guerra age de acordo com a sociedade sobrecodificada em que vive. Do ponto de vista representacional, o fato de a personagem agir e pensar de acordo com as convenções sociais de seu tempo cumpre função idêntica à da Maria da Guerra estática do "eixo documental": servir de modelo da vida fortemente restrita das mulheres da elite colonial, porém com a intensificação do pathos provocada pela narração seletiva.

Além de uma função representacional, a construção da personagem Maria da Guerra exerce também uma função ideológica. Ao ser composta por uma montagem de discursos, Maria da Guerra torna-se menos personagem e mais discussão. A polêmica velada (BAKHTIN, 2018) acerca da baixa idade da noiva, que abre e fecha a cena da preparação do casamento, pode ser destacada para exemplificar esta afirmação.

A insinuação inicial de que Maria da Guerra tem corpo de menina confirma-se ao final da cena descritiva com a declaração: "Daí, então, aos doze anos de idade, passará a mulher". A frase é construída para destacar a incômoda informação sobre a idade da noiva, pois além de ser posicionada entre vírgulas, no meio da frase, a informação é introduzida pela hesitante expressão de origem oral: “daí, então”, comum nas situações em que se vai dar uma notícia ruim. Ao final da frase, o leitor depara-se com a brusca transformação que espera a personagem, sem verbo de ligação: "passará a mulher". 
O casamento de uma menina de doze anos, aceitável e mesmo recomendável na sociedade representada, causa uma tensão com os costumes atuais, para os quais a prática colonial é considerada abusiva. É uma polêmica não declarada, pois não há uma comparação escrita, em Musa Praguejadora, entre as práticas coloniais e as da sociedade atual. Trata-se de uma polêmica velada, no sentido dado por Bakhtin (2018), orientada para o objeto, que é enunciado e representado, o que indiretamente entra em conflito com o discurso do outro.

Depois de introduzida na cena da preparação para o casamento, a informação sobre a baixa idade das noivas na época colonial, objeto da polêmica, é reiterada e ampliada no "eixo documental", em que vigora o ethos do narrador histórico:

\begin{abstract}
Aos doze anos as meninas de família estavam aptas a casar, e casavam com homens escolhidos pelo pai, em geral homens bem mais velhos que, como maridos, assumiam o comando sobre a vida da esposa, antes entregue aos pais e irmãos. A baixa idade das noivas resultava da preocupação com a castidade, e também da situação econômica desfrutada por essas famílias, que não necessitavam das mãos femininas para o trabalho. Além disso, as meninas eram mais fáceis de adestrar e se acostumar à vida de casadas do que as mulheres feitas. (MIRANDA, 2014, p. 58-59)
\end{abstract}

Porém, não apenas os costumes de momentos históricos distintos (o passado colonial e a atualidade) estão em conflito na descrição. A polêmica se dá também, e em especial, entre dois discursos atuais: o gerado por um ponto de vista feminino crítico (o da autora) e o discurso conservador, que ainda hoje preconiza, por exemplo, o casamento de homens mais velhos com mulheres bem mais jovens, a preocupação com a castidade e mesmo o "adestramento" da mulher.

Segundo Bakhtin, o discurso polêmico oculto é bivocal (BAKHTIN, 2018, p. 224), isto é, no enunciado encontram-se o discurso do autor e a representação do discurso do outro, com o qual se dá o conflito. Nos exemplos destacados, o discurso conservador é parodiado tanto no "eixo ficcional": "Este é o dia mais importante de sua vida", "aos doze anos de idade, passará a mulher"; como no "eixo documental": "aos doze anos as meninas de família estavam aptas a casar", "as meninas eram mais fáceis de adestrar e se acostumar à vida de casadas”. Dessa forma, a polêmica com o discurso da autora é estabelecida por meio da paródia, elemento estrutural de Musa Praguejadora. 
Em sua relação de complementaridade com o "eixo documental", no "eixo ficcional" a polêmica velada não aparece somente parodiada no enunciado, mas é também encenada na figura de Maria da Guerra. Portanto, a personagem assume também uma função ideológica, ao representar em seus atos e pensamentos o conflito entre o discurso da autora e o discurso conservador evocado.

Além da realidade social e do cotidiano das mulheres brancas da colônia, por meio de Maria da Guerra, Ana Miranda reconstrói circunscrições de resistência feminina. Conforme o Grande Dicionário Houaiss, "circunscrito" tem entre suas acepções: "que tem os limites materiais bem marcados" e "limitado, restrito". Para o vocábulo "circunscrição", o mesmo dicionário aponta a explicação: “divisão territorial para fins administrativos, eleitorais, eclesiásticos etc." A expressão "circunscrições de resistência" é utilizada aqui a partir da união dos significados de "circunscrito" e “circunscrição", isto é, exprime espaços - físicos, sociais ou psicológicos - nos quais as mulheres exercem resistência à sociedade em que estão inseridas, mas com limitações bem marcadas por essa mesma sociedade.

Um exemplo de circunscrição de resistência individual, que é parte da composição de Maria da Guerra no "eixo ficcional”, encontra-se no final da introdução ao capítulo "Vida de casada":

\footnotetext{
Sente-se feliz quando viaja de barco para a Patatiba, fruindo a soltura do vento, olhando as paisagens a se mover, a vida não é mais parada; e lá, escuta as festas dos negros e dos índios, cantadas e tocadas com ardor. $\mathrm{Na}$ fazenda ela se sente livre, distante das vizinhas e mulheres da família que vigiam seus passos, distante dos que querem governar sua casa, investigar a vida alheia; num isolamento que lhe permite não presumir que deve ser tratada como rainha nem que precise aparecer entre as mulheres como a lua entre as estrelas menores. Ali ela pode acompanhar as conversas de seu esposo com os visitantes, ouvindo da cozinha algumas vezes até mesmo os jogos e beberes que se fazem na varanda, e assistir a comédias, cansada de rir. (MIRANDA, 2014, p. 61, grifos nossos)
}

A circunscrição de resistência é expressa pelas palavras destacadas no trecho acima: "num isolamento que lhe permite...". Assim como a clausura para as freiras, o isolamento na fazenda de cana-de-açúcar representa para Maria da Guerra uma sensação de maior liberdade. A diminuição da vigilância e o arrefecimento das regras sociais permitem-lhe fruir a arte (música e comédias), participar, ainda que apenas como ouvinte, das discussões dos homens e rir. 
A principal distinção entre a vida na cidade e a vida no engenho da Patatiba é estabelecida no início do parágrafo: além de sentir-se feliz, Maria da Guerra percebe que "a vida não é mais parada". A suspensão da imobilidade da personagem é efetuada, em especial, pela sensação de libertação das amarras sociais, o que advém de um conjunto de elementos pertencentes a uma cosmovisão carnavalesca (BAKHTIN, 2018), que compreende, neste trecho: a excentricidade, a quebra da ordem da vida comum, o livre contato familiar e o riso.

É simbólico o deslocamento espacial da cidade da Bahia, centro dos acontecimentos sociais da colônia, para o engenho da Patatiba, no Recôncavo. Trata-se de mudança para um local excêntrico (fora do centro), o que permite, segundo a teoria da carnavalização de Bakhtin, a "violação do que é comum e geralmente aceito" (BAKHTIN, 2018, p. 144), ou seja, "é a vida deslocada do seu curso normal" (BAKHTIN, 2018, p. 144). A sensação de rompimento com a normalidade, esta representada pela vigilância social sobre a vida de Maria da Guerra, é metaforizada por outra importante categoria da cosmovisão carnavalesca: o destronamento. A narração seletiva indica que o isolamento na Patatiba permite a Maria da Guerra "não presumir que deve ser tratada como rainha", uma intencional quebra de hierarquia, que dá lugar a aproximações normalmente interditas, tanto com aqueles que lhe estão socialmente abaixo, por exemplo, os negros e os índios em festa, como com aqueles que lhe estão acima, isto é, os homens que jogam, bebem e conversam na varanda.

O ritual da "coroação bufa" assume formas variadas nos festejos carnavalescos, nos diversos locais onde ocorre e ao longo do tempo, como nos lembra Bakhtin (2018). Mas costumeiramente é composto de três fases: a suspensão da hierarquia social estabelecida (destronamento simbólico do rei), a coroação do rei do carnaval (coroação bufa) e seu posterior destronamento, ao final das festividades. No trecho de Musa Praguejadora ora em análise, o ritual não é completo. Há um destronamento simbólico de representante de categoria mediana na ordem social, uma "rainha", e não ocorre uma "coroação bufa", o que indica uma liberdade apenas relativa de Maria da Guerra em seu isolamento social na Patatiba.

O ritual da "coroação bufa", com a consequente suspensão e mesmo inversão da hierarquia social, permite que entre em vigor outra categoria carnavalesca: "o livre contato familiar entre os homens" (BAKHTIN, 2018, p. 140). Assim como a "coroação 
bufa" não se realiza completamente no trecho analisado, o "contato familiar" também não se dá em plenitude. Maria da Guerra não desocupa seu local mediano na hierarquia social, apenas borra um pouco as linhas divisórias e sua aproximação com as classes acima e abaixo da sua acontece a distância, sem efetiva participação. As festas dos negros e dos índios, ela escuta, talvez da casa-grande. E da cozinha, local simbólico do papel feminino na sociedade, Maria da Guerra pode algumas vezes até mesmo ouvir o divertimento masculino na varanda.

Portanto, há uma diferença entre a sensação de liberdade experimentada pela personagem e a efetiva possibilidade de rompimento com a hierarquia social. Dessa forma, sua resistência é exercida internamente, apenas no plano psicológico, e não no plano da ação.

Mais uma vez, identificam-se as funções representacional e ideológica da construção da personagem. Mesmo em sua circunscrição de resistência, Maria da Guerra continua como modelo do comportamento das mulheres no Brasil colonial, que é mais relaxado no ambiente da fazenda, mas ainda fortemente codificado. Da desconformidade entre a liberdade experimentada pela personagem e sua real possibilidade de desfrute surge a discussão da posição feminina na sociedade, como marca do posicionamento ideológico da autora.

Tanto a função representacional, como a ideológica da construção da personagem Maria da Guerra têm característica "dêitica", no sentido de que remetem o texto para sua enunciação. Essa característica é mais evidente na função ideológica, pois ao encenar uma polêmica velada com os discursos conservadores, da época retratada e os atuais, a elaboração da personagem aponta para o discurso da autora. Na função representacional, o discurso autoral não está diretamente presente, mas sim seu trabalho de seleção dos discursos que compõem a personagem, fruto de suas pesquisas e escolhas ideologicamente condicionadas.

Porém, Maria da Guerra tem também uma função intratextual, no enredo biográfico de Musa Praguejadora. Como mãe do poeta Gregório de Matos, a personagem possui relações genealógicas com o biografado, que são reconstituídas por Ana Miranda para além da herança biológica e de classe. Os interesses e, em alguma medida, a atitude da mãe replicam-se no filho, como nesse trecho sobre a infância de Gregório de Matos: "Na fazenda da Patatiba o menino costuma escutar os índios a 
entoar cantigas que o padre chama de brutais" (MIRANDA, 2014, p. 89). Além do interesse pela música "da terra", tem em comum com a mãe o alívio de estar afastado da cidade: "Ausenta-se da cidade porque o povo maldito da Bahia o põe em guerra com todos, e agora, na Praia Grande, ele vive em paz consigo" (MIRANDA, 2014, p. 271); bem como o prazer dos passeios de barco: "Dali [da Praia Grande, Gregório de Matos] percorria o recôncavo, tomando algum lanchão ou caravelão de carga, ou canoas de pescadores, ou remando ele mesmo pequenos barcos" (MIRANDA, 2014, p. 281-282).

Desse modo, o interesse de Gregório de Matos pela música e seu desejo de liberdade, como construídos em Musa Praguejadora, são características de influência materna. Maria da Guerra, em sua condição feminina, não pode realizar plenamente essas potencialidades, o que no filho, homem, é levado às últimas consequências. Mas pode-se inferir daí a construção de um importante papel feminino na narrativa: a sensibilidade artística de Gregório de Matos, mais desenvolvida na sátira contundente, social ou erótica, é uma herança feminina.

As esposas de Gregório de Matos não têm, em Musa Praguejadora, uma construção que atinja o mesmo grau de complexidade que a de Maria da Guerra, mãe do poeta. Entretanto, cumprem relevantes funções ideológicas e no enredo biográfico, cada qual em seu contexto.

D. Micaela, primeira esposa de Gregório de Matos, aparece pela primeira vez no “eixo ficcional” (MIRANDA, 2014, p. 125-127), durante a visita, imaginada por Ana Miranda, de Gregório de Matos ao convento de Odivelas, na qual o então estudante teria assistido a um sermão de Padre Vieira. Micaela teria comparecido ao convento pelo mesmo motivo, acompanhando a família.

Os jovens trocam olhares e Gregório se interessa pela moça, ainda desconhecida. Ao fim da missa, ele segue a família dela até em casa, ao estilo Marius-Cosette. Na frente do casarão, Gregório interpela o cocheiro e descobre valiosas informações sobre a moça: seu nome, sua origem, sabe que não tem promessa de casamento, informa-se do nome e profissão do pai, que é desembargador, e dos irmãos, advogados. 
O flerte romântico tem um viés bastante pragmático: uma filha disponível em uma família bem-sucedida na área do Direito representa uma oportunidade de futura estabilidade e ascensão profissionais para o jovem estudante. A paixão adolescente é real, mas diferente da dedicada às freiras e às mulheres do Rocio. É conformada pelo interesse no compromisso de casamento e os protocolos que a situação exige.

Essa visão é confirmada no capítulo “O que é o amor?” (MIRANDA, 2014, p. 165-170). Formado Bacharel e Doutor, Gregório de Matos vai voltar a Lisboa e o primeiro pensamento que lhe ocorre é reencontrar D. Micaela (MP, p. 165). Após devaneios amorosos, montados por Ana Miranda a partir de poemas de Gregório de Matos, o recém-formado viaja à capital, enquanto reflete:

Em sua solidão, diante do desafio a enfrentar, arranjar um meio de vida, dona Micaela e sua família seriam um esteio, um abrigo. O pai da moça, o desembargador, e os irmãos, conhecem os meios, os corredores, são do mundo dos juízes, dos corregedores, irão mostrar-lhe caminhos, abrir-lhe portas. (MIRANDA, 2014, p. 166)

No "eixo documental" Ana Miranda revela que a visão utilitarista do casamento era usual no tempo de Gregório de Matos, uma vez que casar era obrigatório para se adquirirem plenos direitos na sociedade: "Casar era um passo importante para qualquer homem português; apenas os casados, sobretudo os que tinham filhos e criados, podiam exercer certos cargos públicos e fruir de plenos direitos políticos” (MIRANDA, 2014, p. 171).

Casado, a carreira de juiz de Gregório de Matos em Portugal se inicia e entra em progressiva ascensão. Apesar de, aos poucos, tender para a vida boêmia, paralela à vida de casado, o juiz: "toma a sério o cargo e desempenha seu papel com isenção e justiça" (MIRANDA, 2014, p. 184).

A morte precoce de dona Micaela desprende a natureza boêmia de Gregório. Na interpretação ficcional de Ana Miranda: "Aos poucos volta à boêmia, à sátira, à estroinice, à chalaça, aos jogos de cartas, à viola, aos catres das damas no Mocambo..." (MIRANDA, 2014, p. 217). O trecho é inspirado em Pedro Calmon, que Ana Miranda cita em seguida, ainda dentro do "eixo ficcional": "A perda da esposa cindiu-lhe o destino. Para trás ficaram os brios da inteligência culta; para diante, o abismo da graça e da aventura. Fechou o livro, deu-se à sátira, à estroinice, à chalaça..." (CALMON. Apud: MIRANDA, 2014, p. 217). 
De personagem ausente na biografia pioneira escrita por Manuel Pereira Rabelo, e das primeiras que a seguiram, dona Micaela passa a entidade estratégica no enredo da vida de Gregório de Matos, em suas biografias modernas, inclusive em Musa Praguejadora. Seu casamento com Gregório de Matos representa o vínculo do poeta com a carreira de Juiz e com Portugal. O desenlace da esposa, portanto, foi interpretado pelos biógrafos como um rompimento com esses dois fatores, fazendo surgir o poeta satírico e reavivando sua ligação com a terra natal, visão reproduzida por Ana Miranda.

Para Calmon, a perda da esposa resulta na decadência de Gregório de Matos, que troca "os brios da inteligência culta" pela aventura e pela sátira, isto é, pela vida desregrada e pelo estilo baixo. Já Ana Miranda constrói uma passagem pautada na dor, e não no simples desejo de aventura, apesar da referência a Calmon no seu texto. Na elaboração da romancista, após a morte de dona Micaela, Gregório "escreve poemas inspirados pela dor". E conclui: "Madruga nas ruas, evitando a cama fria da solidão". Portanto, o poeta da maturidade surge do sofrimento, elemento constitutivo da sátira, que dramatiza o rancor e provoca dor pela maledicência (HANSEN, 2004, p. 88).

O casamento com Maria de Povos, segunda esposa de Gregório de Matos, dá-se em circunstâncias completamente diferentes do casamento com dona Micaela. Na ocasião, Gregório já tem 52 anos de idade, passou pelo apogeu de sua carreira no Direito e tem consumada sua fama de poeta e boêmio. Mas o casamento preserva, no enredo de Musa Praguejadora, ainda que de maneira mais sutil, o aspecto pragmático.

Não há que se falar em construção de personagem para Maria de Povos na biografia romanceada em análise. O pouco de sua psicologia e de suas características físicas não chegam a dar "vida" à personagem no enredo. Sabe-se que é bela, viúva e pobre, além dos nomes de seu tio e de seus pais, informações que têm origem na biografia de Manuel Pereira Rabelo e foram repetidas nas demais, inclusive em Musa Praguejadora. Suas ações são descritas por discursos de outros, de maneira complexa, mas nunca direta, ou são conjecturadas pelo narrador.

No “eixo ficcional”, Ana Miranda narra o cortejo de Gregório de Matos a Maria de Povos usando colagem de poemas atribuídos ao poeta seiscentista, bem como das didascálias a eles relacionadas. A escrita em palimpsesto na sequência do cortejo tende a um mis en abyme de discursos sobrepostos, como em camadas. Destaquemos um trecho dessa sequência, para ensejar a análise: 


\begin{abstract}
Maria de Povos se recata com prudência das demasias de seu futuro esposo, ele avalia esse desdém por tirania, e vai aos montes escarmentar, punir seu sentimento. Fala com os montes, tenta se aliviar, pede perdão por seus ais e por interromper o silêncio da paisagem, os montes já sabem que ele ama, estima, quer, adora. Mas de que serve cansá-los? Os montes já sabem que o poeta morre por conta daqueles olhos irosos que lhe parecem raios. O poeta pensa nos ricos cabelos que, na oficina dos ombros, se reformaram em meninas de anéis preciosos. Lembra o rosto gentil onde se vê um não sei quê escondido, que o matou, não sabe como. Lembra logo a muita alma com que Maria move o corpo airoso e o assombra. Ele deseja poder mostrar as partes que esconde, em recato, quando as poderia dizer vanglorioso. Lembra, enfim, Marfida, a musa poética de Montemayor, mas... O que diz? O que conta aos montes? Porque se de Maria jamais se esquece, como se recorda! (MIRANDA, 2014, p. 364, grifos nossos)
\end{abstract}

Na primeira camada, reconhece-se o poema "Montes, eu venho outra vez..." (MATOS, 1990, p. 508-510) como hipotexto principal. Considerada a controversa autoria dos poemas sempre apógrafos atribuídos a Gregório de Matos, não há comprovação histórica de que esse poema tenha sido escrito a Maria de Povos, como nem mesmo há garantia de que seja composição de Gregório de Matos.

Também a didascália referente ao poema encontra-se citada (parte destacada em negrito no trecho transcrito): "Recatava-se prudentemente esta belleza das demazias de seu futuro esposo, mas elle avaliando este desdem por tyrannia recorre segunda vez aos montes, como escarmentado de amor no primeiro objecto" (MATOS, 1990, p. 508).

A terceira camada corresponde não a uma referência textual, mas ao trabalho de edição de James Amado, uma vez que a sequência que narra o cortejo de Gregório de Matos a Maria de Povos é elaborada a partir de poemas retrabalhados por Ana Miranda que estão na mesma ordem em que aparecem no item 4 - Maria, do capítulo III - A cidade e seus pícaros, da Obra poética editada por Amado (MATOS, 1990). A organização temática da Obra poética foi feita a partir da interpretação das didascálias dos poemas contidos nos vários códices cotejados pelo pesquisador baiano. Portanto, a aparente sequência narrativa do item dedicado a Maria de Povos foi uma escolha de James Amado, e não uma ordem cronológica pré-estabelecida.

A quarta e última camada corresponde ao hipertexto de Ana Miranda, derivado de todas as camadas anteriores, retrabalhadas pela autora. Sua principal interferência é a mudança da voz narrativa para seletiva, no lugar do discurso indireto da didascália e do discurso direto do poema. Como consequência, o narrador de Musa Praguejadora apodera-se da condução da narrativa, e funciona como peça articuladora das outras 
camadas discursivas, de modo a nivelá-las num mesmo plano temporal, que é o da narrativa.

Em nenhuma das três camadas discursivas que servem de base ao texto de Ana Miranda pode-se reconhecer elementos biográficos seguros, em especial de Maria de Povos. Os poemas atribuídos a Gregório de Matos utilizados na sequência do cortejo são compostos a partir de topoi comuns na poesia lírica, como: o convite amoroso, a invocação à natureza, o sofrimento amoroso, entre outros. As indicações das didascálias, que relacionam os poemas à esposa de Gregório de Matos, bem como a organização dos poemas por James Amado, que cria uma sequência de cortejo amoroso, são criações ficcionais, intencionais ou não. Trata-se do problema levantado por João Adolfo Hansen (2004a) sobre a ação "produtiva e deformante" da recepção da obra atribuída a Gregório de Matos.

O texto de Ana Miranda não desconsidera nenhum elo do encadeamento da recepção dos poemas. Ao contrário, cria uma síntese na qual as camadas discursivas ao mesmo tempo se encaixam e estão em atrito, isto é, produz um texto que ratifica a interpretação biográfica dos poemas, geradas por sua recepção, como preserva características originais dos poemas, que desacreditam tal interpretação. Portanto, a sequência do cortejo de Gregório de Matos a Maria de Povos, em Musa Praguejadora, cumpre um papel que serve mais às características metaficcionais da obra, que à constituição da personagem Maria de Povos.

$$
* * *
$$

As freiras, como todas as mulheres indisponíveis para o casamento, eram vítimas de mordazes sátiras, de Gregório de Matos e outros poetas do seu tempo. Em especial as mulheres com alguma ou bastante liberdade sexual, religiosas ou não, eram expostas ao julgamento público pelos mais ofensivos versos.

Nessa situação encontravam-se as mulheres não brancas. Em trecho não ficcional de Musa Praguejadora, Ana Miranda afirma:

A sociedade de seu tempo - e ele mesmo [Gregório de Matos] - fazia uma grande distinção entre moças brancas, presas em casa, e mulheres que andavam nas ruas, quase sempre mulatas ou negras, escravas ou libertas". (MIRANDA, 2014, p. 248) 
O trecho reitera a afirmação de Alfredo Bosi: “A dignificação ou o aviltamento da mulher tem cor e tem classe neste poeta arraigado em nossa vida colonial e escravista" (BOSI, 1992, p. 109). Conforme a análise do crítico, a poesia lírico-amorosa de Gregório de Matos estava reservada às mulheres brancas e socialmente bem-postas. Já as mulheres negras e mestiças: "se convertem em objeto misto de luxúria e desprezo" (BOSI, 1992. p. 107). Bosi conclui: "Há, portanto, uma desclassificação objetiva da mulher que nunca se tomaria por esposa, situação que a cor negra potencia [...]" (BOSI, 1992, p. 109, grifos do autor).

Para João Adolfo Hansen, a questão é mais de poética, que de escolha pessoal ou social do poeta. Segundo o crítico:

No caso da sátira ibérica seiscentista, mulheres não-brancas são, por definição, uma sub-humanidade relegada ao topos da gentilidade e mesmo da bestialidade pelos códigos teológico-políticos da Conquista e o estilo para tratá-las como tema deve ser cômico ou baixo, para ser verossímil". (HANSEN, 2004, p. 52)

Em Musa Praguejadora, a relação poética de Gregório de Matos com as mulheres é marcada por constantes inversões, que compõem um quadro complexo da sociedade descrita e da construção da identidade do biografado. Ao tomar poemas como experiências amorosas e sensuais do poeta baiano, Ana Miranda reforça a tradição crítica que se estabeleceu em torno de Gregório de Matos, que trata como documentos da vida empírica os poemas a ele atribuídos (HANSEN, 2004). Por outro lado, em determinadas passagens, a autora retira a legitimidade dos poemas como registro documental, seja despersonalizando a atitude de Gregório, atribuída ao comportamento geral dos homens do seu tempo, seja reproduzindo trechos de seus poemas no "eixo ficcional" da obra.

A complexidade das afirmações oscilantes e contraditórias na metabiografia de Ana Miranda é resultado, dentre outros procedimentos literários, de uma estrutura com características dialógicas (BAKHTIN, 2018). Embora a enunciação no "eixo documental" de Musa Praguejadora seja realizada por uma voz seletiva e organizadora do material citado, como é típico do gênero biográfico, e mesmo que Ana Miranda frequentemente misture a seu texto os textos consultados, fica preservada certa autonomia de consciência dos pesquisadores aos quais a autora recorre, de forma que é 
possível reconhecer seus discursos. Há supressão das diferenças temporais e os discursos do próprio Gregório de Matos, seus biógrafos, historiadores de diversas épocas e da autora coexistem na construção da narrativa biográfica. Das relações dialógicas entre essas diversas vozes, surgem conflitos e contrapontos (BAKHTIN, 2018) que não se resolvem e, por isso mesmo, levam à reflexão sobre as representações histórico-biográficas da obra.

Assim, no capítulo "Mais corredia que a água: o poeta e as mulheres", por exemplo, Ana Miranda afirma que: "O poeta era louco pelas mulheres. Quando não estava apaixonado por uma, estava apaixonado por todas" (MIRANDA, 2014, p. 248). Destaca, na sequência, a assiduidade do poeta às mulheres mulatas, pardas e negras. Sendo afirmação do "eixo documental", é ratificada por citação de obra consultada pela autora, neste caso, a biografia de Gregório de Matos escrita pelo historiador Pedro Calmon:

Será, em língua portuguesa, o mais franco apologista de seus encantos [os das mulheres pretas e mulatas]. Apaixonado da capitosa morena do seu país, estendeu-lhe aos pés a adulação, pintando com amor explosivo, a Vênus de jambo como se fosse, de mármore clássico, a deusa grega... (Apud MIRANDA, 2014a. p. 248)

A ilustrar a passagem, seguem-se trechos do "eixo ficcional", nos quais Ana Miranda retrabalha poemas de Gregório de Matos. A operação resulta em grande ambiguidade para a apreensão do texto como escrita biográfica e para a compreensão da relação do poeta com as mulheres não brancas.

O primeiro dos dois trechos, encerra-se com o rebaixamento das mulheres mestiças, bem como do próprio poeta, que se envolve com elas:

\footnotetext{
Quem goza, com elas, tantos prazeres e é amado e obedecido de tantas ninfas no dourado tapete dos bem-me-queres, merece a zombaria de pobre emigrado [...]. O amor dele se vangloria, quando ele está cercado de peixeiras, e ainda mais triste do que uma bebedeira; as mulatas na Bahia arrastam mulas e fedem a peixe como o diabo, mas pouco importa serem gritadeiras... (MIRANDA, 2014, p. 249)
}

O texto contraria as afirmações de Calmon. O suposto "apologista de seus encantos" afirma que as mulatas "arrastam mulas e fedem a peixe", imagem muito diferente da "Vênus de jambo" que o historiador baiano presume ser cantada pelo poeta. O trecho acaba por ressaltar a idealização da figura biográfica de Gregório de Matos 
construída por Calmon. E, por inversão, a criação literária assume uma conotação mais realista que o texto pertencente ao eixo documental, por revelar mais propriamente a condição da mulher não branca na sociedade colonial e por corresponder às práticas literárias vigentes na época de Gregório de Matos. Portanto, num jogo dialético, o poema, pertencente ao eixo ficcional, é desautorizado como documento, por ser criação literária e, ao mesmo tempo, esse mesmo poema desautoriza o discurso romantizado do eixo documental, emergindo como um discurso mais fidedigno.

O segundo trecho utilizado para exemplificar a relação do poeta com as mulheres não brancas é a reescrita, para a forma narrativa, do poema dedicado à negra denominada Supupema. Na recriação de Ana Miranda, assim como no poema original, Supupema é tida por "bonita como umas flores e alegre como umas páscoas". Ao final do poema reescrito, consta:

Ele é uma infelicidade para ela, mas para agradá-la ele seria o Bagre, o negro que tem as pernas inchadas. Claro, ele não é negro, ela sabe, se ele o fosse, ela o buscaria. Ele nunca se arroga a branco. Seu pai nunca lhe ensinou a ser branco de cagucho e cara. Pede a Cipriana que não deixe de querê-lo, só porque é branco de casta, porque, se ela o tiver cativo, ele será seu negro, seu canalha. (MIRANDA, 2014, p. 250)

A submissão da persona poética, identificada aqui como o personagem Gregório de Matos, pode fazer supor uma vassalagem amorosa. Mas nem o que se analisou sobre o trecho anterior, nem a estrutura da sátira seiscentista permitem essa única interpretação. Uma vez que os modelos poéticos da sátira ibérica preceituam a referência à mulher negra no estilo cômico ou baixo, os elogios iniciais a Supupema devem ser compreendidos como inversão irônica, assim como o rebaixamento da persona poética é uma autoexposição do vício de quem se conspurca no desejo pela mulher negra, entendido naquela sociedade como bestial.

O trecho citado acima, como grande parte da obra, permite dupla interpretação: tanto ratifica a imagem romantizada do poeta enamorado dos encantos das mulheres negras de seu país, como ressalta o racismo e o desprezo com os quais essas mulheres são tratadas pela poesia de Gregório de Matos (e sua sociedade).

Os capítulos dedicados às tentativas de casamento de Gregório de Matos, em que entram em cena as mulheres brancas, seguem estrutura semelhante aos trechos citados: as peripécias amorosas são narradas no eixo ficcional, com trabalho da autora sobre 
poemas do biografado. A diferença é que o elogio da mulher é realizado por meio da poesia lírica, reafirmando a observação de Bosi (1992) de que o estilo alto estava reservado às mulheres brancas. No entanto, assim como nos exemplos relativos às mulheres negras, a maioria das narrativas de galanteio termina com insultos do poeta às mulheres que acederam ao assédio.

No capítulo que trata de Babu, após a narrativa dos amores entre ela e Gregório, Ana Miranda adiciona considerações, no "eixo documental", sobre a atitude de seu biografado de perder "o interesse e o respeito pela mulher que não se negasse" (MIRANDA, 2014, p. 392). No livro, Babu foi uma moça cortejada pelo poeta, mesmo sendo ele casado, e acaba por se entregar sexualmente ao assediador, ocasião que marca uma brusca mudança de tratamento poético, da lírica para a sátira.

Uma vez que o sexo fora do casamento era proibido no século XVII, em especial para as mulheres, sua prática era passível de sanções, tanto pela aplicação das leis, como por sanções sociais, tais como o repúdio, a exposição e a vituperação da infratora. Nesse sentido, a sátira era um dos dispositivos judicativos por meio dos quais a sociedade renascentista defendia suas regras morais e suas hierarquias (HANSEN, 2004).

Hansen também alerta que: "A sátira não é realista [...], porque tem direção referencial, mimetizando casos retóricos, não o referente" (HANSEN, 2004, p. 102). Portanto, a sátira tem a dupla função de punir e de prevenir ações que estejam em desacordo com a ordem social. A pessoa satirizada pode ou não ter cometido o ato exposto na criação poética (elaborada de acordo com os preceitos clássicos), como pode mesmo não existir objetivamente e ser recriação de lugares-comuns retóricos.

Em Musa Praguejadora, conforme sua estrutura dialética, as mulheres da elite citadas na obra têm existência, ao mesmo tempo, objetiva e ficcional. Há informações documentais sobre dona Ângela de Sousa Paredes, como por exemplo: seu ano de batismo e dados sobre seus familiares (MIRANDA, 2014, p. 309), o que indica que a personagem teve existência histórica. No entanto, usando a criação literária como apoio no "eixo documental", Ana Miranda afirma: "Mas, pelos poemas, sente-se que a própria dona Ângela o recusava” (MIRANDA, 2014, p. 309).

Há referências a Babu também no "eixo documental", mas os dados são duvidosos, como: "Há um último poema a Babu, ou Bárbara, que Rabelo chama de 
'mulata meretriz'. Mas Babu, pelos versos do poeta, era alva como a neve, e não parecia ser meretriz" (MIRANDA, 2014, p. 391).

Não só há controvérsia sobre a cor de pele da personagem e o fato de ser ou não meretriz, como ambos os documentos utilizados são de cunho possivelmente ficcional. A mais antiga biografia conhecida de Gregório de Matos, escrita por Manuel Pereira Rabelo, provavelmente na primeira metade do século XVIII, foi tida por muitos críticos como narrativa dos fatos da vida do poeta. No entanto, o texto de Rabelo é uma "fícção biográfica", escrita de acordo com os preceitos retóricos do gênero biográfico clássico (HANSEN, 2004). Assim, no confronto de dados controversos acerca de Babu, Ana Miranda prioriza a criação poética sobre o texto que poderia ser alçado à trabalho biográfico, embora ele mesmo seja questionável como documento da vida de Gregório de Matos.

Embora possa haver resquícios de sua existência objetiva, essas mulheres são construídas tanto nos documentos de referência, como no texto de Ana Miranda, como ficções com funcionalidades específicas. Como objetos da sátira de Gregório de Matos, sua função é representar o sexo desonesto, punível pelo Estado e pela Igreja e, independentemente de esses atos terem sido praticados ou não, provocar no público a culpa por sentir desejos análogos (cf. HANSEN, 2004, p. 420-421). Dialeticamente, no trabalho literário de Ana Miranda, essas mesmas personagens representam atos de resistência e liberdade das mulheres na sociedade patriarcal. Ilustrar-se, aprender música e poesia e, principalmente, realizar desejos sensuais eram vistos, no século XVII, como delitos morais, se praticados pelas mulheres. Para Ana Miranda, no entanto, são atitudes que ensejaram registros hibridamente poéticos e históricos e que revitalizam o olhar sobre as mulheres, desde que lidos para além do moralismo patriarcal e dos códigos da sátira clássica.

Essa leitura é possível se também a obra de Ana Miranda for abordada para além da rigidez de um pacto biográfico que busca aproximar-se da "verdade". O trabalho da escritora cearense ressalta os limites e as possibilidades do hibridismo da linguagem biográfica e, nesse sentido, reitera a afirmação de François Dosse: “... ao biógrafo não importa muito a verdade: deve, isso sim, criar traços humanos, muito humanos" (DOSSE, 2015, p. 57). 
Portanto, as personagens femininas em Musa Praguejadora têm um status híbrido, isto é, são mulheres que podem ter interagido com Gregório de Matos e também são personagens de poesias, como demonstra o trecho:

\begin{abstract}
A maioria das mulheres, Gregório de Matos encontrava por acaso, em suas andanças na cidade e no recôncavo. ocorrendo conquistas e fracassos. Algumas dessas mulheres foram personagens de diversas poesias, e outras, apenas mencionadas num verso. Gregório de Matos foi generoso em seu acervo de personagens femininas, deixando um variado "ramilhete de flores". (MIRANDA, 2014, p. 402-403)
\end{abstract}

Não importa muito à autora reconstituir a existência histórica de cada uma dessas mulheres - trabalho que seria, ademais, impossível, diante da ausência de documentos. Importa-lhe muito mais constituir personagens femininas com densidade humana e sociológica, a partir do resgate dos discursos construídos acerca das atitudes das mulheres no século XVII, em especial, a poesia de Gregório de Matos. Nesse processo de reconstrução da figura feminina, Ana Miranda ressignifica o objeto da sátira, e as atitudes que motivam a censura passam a sinais de resistência das mulheres à sociedade patriarcal. Desse modo, o discurso da sátira é posto à prova da passagem do tempo, e o leitor questiona-se sobre sua validade nos dias de hoje.

Nesse sentido, finalmente, vale lembrar que "O ramilhete de flores" é o título dado por Ana Miranda à "Antologia das personagens femininas de Gregório de Matos", elaborado em forma de glossário e inserido como última informação autoral do livro, antes dos créditos das imagens e da bibliografia. Nesse apêndice, cada personagem feminina ganha densidade psicológica, a partir de um conjunto de características retiradas dos poemas de Gregório de Matos nos quais ela é citada. São mulheres como as freiras Clara, Maria e Branca, que "tocavam e cantavam na capela de Nossa Senhora das Neves" (MIRANDA, 2014, p. 520); como Francisca de Sande, "pioneira da enfermagem feminina no Brasil" e que cuidou "pessoalmente de doentes da peste de 1686" (MIRANDA, 2014, p. 523); como Macotinha, que “esteve na festa das juízas e mordomas, embebedando-se"; e Joana Gafeira, que era "fedida de catinga de sovaco" (MIRANDA, 2014, p. 525). Além de personagens históricas e de objetos poéticos, são mulheres muito humanas, que se arriscavam no gozo do era proibido.

\title{
Referências
}


BAKHTIN, Mikhail. Problemas da poética de Dostoiévski. 5. ed. Rio de Janeiro: Forense Universitária, 2018.

BOSI, Alfredo. Do antigo Estado à máquina mercante. In: Dialética da colonização. São Paulo: Companhia das Letras, 1992. p. 94-118.

GUEDES, Diogo. Ana Miranda fala sobre a recriação de Gregório de Matos e seus interesses literários. Recife, JC Online, 06 set. 2015. Disponível em: https://jc.ne10.uol.com.br/canal/cultura/literatura/noticia/2015/09/06/ana-miranda-falasobre-a-recriacao-de-gregorio-de-matos-e-seus-interesses-literarios-197682.php. Acesso em: 30 jan. 2021.

HANSEN, João Adolfo. A sátira e o engenho: Gregório de Matos e a Bahia do século XVII. 2. ed. rev. São Paulo: Ateliê Editorial; Campinas: Editora da Unicamp, 2004.

HUTCHEON, Linda. Poética do pós-modernismo: história, teoria, ficção. Rio de Janeiro: Imago, 1991.

MIRANDA, Ana. Musa Praguejadora: A vida de Gregório de Matos. Rio de Janeiro: Record, 2014.

(org). Que seja em segredo: Escritos da devassidão nos conventos brasileiros e portugueses dos séculos XVII e XVIII. Porto Alegre: L\&PM, s/d. E-book. BAKHTIN, Mikhail. Problemas da poética de Dostoiévski. 5. ed. Rio de Janeiro: Forense Universitária, 2018.

MATOS, Gregório de. Obra poética. Edição de James Amado. 2. ed. Rio de Janeiro: Record, 1990. 2V.

MIRANDA, Ana. Musa Praguejadora: A vida de Gregório de Matos. Rio de Janeiro: Record, 2014.

(org). Que seja em segredo: Escritos da devassidão nos conventos brasileiros e portugueses dos séculos XVII e XVIII. Porto Alegre: L\&PM, s/d. E-book.

Recebido em: 31/01/2021 Aceito em: 12/04/2021

\footnotetext{
${ }^{1}$ Neste artigo, foi utilizada a edição digital (ebook) da antologia Que seja em segredo, conforme consta nas referências.
} 